\title{
TOLERANCE TO DISTURBANCE REGULATED BY ATTRACTIVENESS OF RESOURCES: A CASE STUDY OF DESERT BIGHORN SHEEP WITHIN THE RIVER MOUNTAINS, NEVADA
}

\author{
Christopher Lowrey1,2 and Kathleen M. Longshore ${ }^{1}$
}

\begin{abstract}
Human activity may mimic predation risks for wildlife by causing abandonment of foraging sites and increasing expenditure of energy. Animals that can tolerate nonlethal disturbance may minimize these fitness costs. We examine this aspect of the risk-disturbance hypothesis by first analyzing recent habitat use of desert bighorn sheep relative to areas of attraction and disturbance. We then compare and contrast sheep responses to differing levels of anthropogenic disturbance between 2 time periods, 30 years apart. Desert bighorn sheep were tolerant of suburban activity when a consistent forage resource (municipal grass) was provided. Males were more tolerant than females, and females returned to natural, steep areas during the birthing season. Increased recreation activity, specifically mountain bike use, may have resulted in avoidance by sheep of otherwise suitable habitat that had been occupied decades earlier, thereby reducing availability of limited habitat. Tolerance increased only when attractiveness was relatively high and decreased as perceived fitness decreased, supporting risk-disturbance theory.
\end{abstract}

Resumen.-La actividad humana puede imitar los riesgos de depredación de la vida silvestre al provocar el abandono de sitios de forrajeo y aumentar el gasto energético. Los animales que toleran perturbaciones no letales pueden minimizar estos costos en su adecuación. Examinamos esta hipótesis de riesgo por perturbación al analizar, en primer lugar, el uso reciente del hábitat del borrego cimarrón del desierto en relación con áreas de atracción y perturbación. Después, comparamos y contrastamos la respuesta de los borregos a diferentes niveles de perturbación antropogénica entre dos períodos de tiempo (30 años de diferencia). Los animales toleraban la actividad suburbana cuando se les proporcionaba un recurso de forrajeo consistente (pasto municipal). Los machos fueron más tolerantes que las hembras, y las hembras regresaron a las áreas empinadas naturales durante el período reproductivo. El aumento de la actividad recreativa, específicamente el ciclismo de montaña, pudo haber resultado en evitar un hábitat adecuado que había sido ocupado desde décadas atrás, reduciendo la disponibilidad del hábitat. La tolerancia aumentó sólo cuando el atractivo fue relativamente alto, y decreció a medida que disminuyó la adecuación, apoyando la teoría de riesgo por perturbación.

How wild animals manage risks ensuing from anthropogenic activity is an increasingly active field of research as ecologists recognize that humans can indirectly influence animal behaviors. As human-wildlife interactions increase, understanding the limits of animal tolerance to human disturbance becomes more critical for sound science-based management practices (Gill et al. 1996, Taylor and Knight 2003, Manor and Saltz 2005). A theoretical framework for making predictions had rarely been used in wildlife research until economic models of anti-predator behavior, often referred to as risk-disturbance models, were applied to disturbance studies (Gill et al. 2001, Frid and Dill 2002). Animals must trade off the risk of predation with fitness-enhancing behaviors such as foraging and mate selection (Lima 1998, Pauli and Buskirk 2007), and disturbance may be perceived similarly to predation risk (Frid and Dill 2002). The risk resulting from human activity may force animals toward responses that reduce fitness, such as altering habitat-use patterns (Johnson et al. 2002), increasing vigilance (Loehr et al. 2005), and increasing flight response (Stankowich 2008). Decisions made by animals in response to disturbance depend on the intensity of the disturbance, the quality of the disturbed site in relation to adjacent sites, and the relative risk of predation and density of competitors in different sites (Ydenberg and Dill 1986, Frid and Dill 2002, Mao et al. 2005).

Human disturbance and encroachment is a major contributor to habitat loss (Bender et al. 1998, Markovchick-Nicholls et al. 2008), and many populations are increasingly, if not completely, isolated in ever-shrinking environments as human populations continue to grow (Singer et al. 2000a, Rubin et al. 2002). 
Populations that are isolated by urban encroachment are subject to the stresses of repeated disturbance from recreation activity, noise, and visual disturbances (Dyer et al. 2001, Naylor et al. 2009), potentially leading to declines in productivity (Nellemann and Cameron 1998) and carrying capacity (Light and Weaver 1973). Repeated energetic losses due to flight and loss of foraging time can be cumulative over time (Graham 1971, Etchberger et al. 1989), causing detrimental effects on physiology and behavior that lead to reduced survival and reproductive success (MacArthur et al. 1979, DeForge 1981).

Conversely, some disturbed areas can serve as strong attractants to wildlife (Krausman et al. 2006). Water and forage are often provided for wildlife to both support stressed populations and to augment limited resources (Cooper et al. 2006). In other cases, wildlife are attracted to resources within areas not designed for them, such as parks, golf courses, suburban lawns, etc. Animals must tolerate relatively high levels of disturbance to exploit these novel resources, and questions about the effects these attractants have upon the longterm fitness of a naïve population remain largely unanswered.

How animals in isolated or restricted habitats respond to human disturbance or attractiveness is an understudied area of research due in part to the difficulty in quantifying fitness (Krausman et al. 2006). In lieu of direct fitness measures, identifying changes in habitat use as a function of differing levels of disturbance can provide important insights into the long-term effects of disturbance (Beyer et al. 2013, Ordiz et al. 2013) and can also help identify management strategies that can best mediate the detrimental effects of human activity (Moreau et al. 2012). In less geographically restricted areas, animals with available habitat of similar quality nearby can avoid disturbance because they have alternative sites to occupy. In areas where suitable habitat is limited, however, animals may be forced to remain despite the disturbance, regardless of whether survival or reproductive success is affected (Frid and Dill 2002).

Studies of disturbance-caused changes in habitat use, ranging from short-term avoidance (Longshore et al. 2013) to complete abandonment (Welles and Welles 1961, Light 1971), are most useful when the time span is long enough to ensure confidence in the causative nature of the response (Altmann 1974). Many studies have a short time frame relative to the lifespan of the species in question (Krausman et al. 1989, Frid and Dill 2002). This may lead to changes in habitat use being attributed to short-term anthropogenic events, which may or may not be the case. Studies that alternatively compare habitat use over longer periods of time are better suited to determine anthropogenic effects on habitat use and distribution (Gill et al. 1996).

Desert bighorn sheep (Ovis canadensis nelsoni) populations of the Southwest are threatened by many human activities (Singer et al. 2000a, Gutierrez-Espeleta et al. 2001, Papouchis et al. 2001). Human disturbance has resulted in the abandonment of habitat and extirpation of bighorn sheep populations in several regions of the Southwest (Graham 1971, King 1985, Etchberger et al. 1989). Human disturbance was also a factor contributing to the listing of the California peninsular population of desert bighorn sheep (O. $c$. cremnobates) as an endangered population (USFWS 2000). In light of these findings, determining tolerance of bighorn sheep to different levels of human activity has become a vital conservation issue. In the River Mountains, Nevada, human encroachment from suburban sprawl, housing developments, and major highways has almost completely isolated the desert bighorn sheep population from its surrounding metapopulation. Growth in the adjacent Las Vegas, Nevada, metropolitan areas has increased dramatically over the past several years (www.clarkcountynv.gov), which has resulted in a sharp increase in hiking, offroad vehicle use, and mountain biking, including the construction of an extensive mountain bike trail system within the range. This bike trail system receives thousands of visitors a year and encompasses the full elevation range of bighorn sheep habitat within its boundaries. Other major anthropogenic changes in the River Mountains include Hemenway Municipal Park (constructed in 1985) and Cascata golf course (1998), which provide easily accessible water and forage resources for bighorn sheep year-round. Resource managers are therefore justified in their concern about increased human disturbance of desert bighorn sheep inhabiting the River Mountains, Nevada. 
The risk-disturbance hypothesis predicts that habitat use by desert bighorn sheep will be altered as a function of both the level of disturbance and the attractiveness of forage resources. In this paper, we use our data to test the following predictions of this hypothesis: (1) animals will tolerate greater perceived risks (i.e., a novel or increased human disturbance level) in areas with specific attractive resources such as water sources or artificially watered forage, (2) animals will have reduced tolerance to perceived greater risk in areas of natural habitat without specific attractive resources, and (3) levels of tolerance toward human disturbance will interact with time of year as a result of shifts in bighorn sheep foraging and reproductive needs. To test these predictions, we use recently collected (2003-2004) bighorn sheep locations to model recent habitat use and determine how this use is affected by artificial water/forage areas both year-round and seasonally for males and females. We then compare and contrast this recent habitat use with historic (1970-1978) habitat use, which occurred before the municipal park and mountain bike park were completed. This comparison is achieved by interpreting categorical time periods by variable interaction terms within a single logistic regression model. In order to provide useful information for managers, our goals were to determine (1) whether any changes in habitat use occurring between these time periods are due to the attraction and/or disturbance of man-made areas and human activities, (2) whether habitat has become more or less available to bighorn sheep due to these activities, and (3) whether any changes in habitat use are seasonal. We do not assume to know whether any changes occurred immediately or several years after the creation of these disturbed areas. We do contend, however, that foraging and reproductive changes resulting from the creation of these areas may have long-term consequences for bighorn sheep.

\section{Methods}

\section{Study Area}

The River Mountains are within the Mojave Desert region approximately $24 \mathrm{~km}$ southeast of Las Vegas, Nevada. The range is relatively isolated on the north, west, and south by suburban development and on the east by Lake
Mead. Major highways also bound the range on the western and southern edges. Several dirt roads infiltrate the western side, and a major mountain bike park, a golf course, and a municipal park occur on the southern edge. Growth in the surrounding metropolitan areas has increased dramatically over the past several years, resulting in increased recreational activity in the range. The elevation ranges between $400 \mathrm{~m}$ and $1155 \mathrm{~m}$ and the topography is generally steep, rocky, and treeless (Fig. 1). Creosote bush (Larrea tridentata) and burrobush (Ambrosia dumosa) are the dominant vegetation associations, with major species including Atriplex spp., Encelia farinosa, Dalea spp., Ephedra nevadensis, and Krameria parvifolia (Leslie and Douglas 1979). Average rainfall is $<15.0 \mathrm{~cm}$ per year, with most occurring in the winter and summer months.

\section{Bighorn Sheep Captures}

Bighorn sheep locations were recorded with GPS units to determine current seasonal habitat use, to measure recent use against historic use, and to determine changes in habitat use due to anthropogenic effects. On 25-26 October 2003, 13 adult desert bighorn sheep-8 females and 5 males-were captured within the River Mountains, Nevada. Cooperating agencies involved in the capture operation were the U.S. Geological Survey, National Park Service, and the Nevada Department of Wildlife (NDOW). The Fraternity of the Desert Bighorn, a nonprofit organization, also provided logistical support. Animals were captured by use of a net gun fired from a helicopter. Each animal was blindfolded, immobilized with leather straps, and processed at the respective capture sites. No immobilizing drugs were administered. Physiological measurements and samples of blood, mucus, and feces were immediately collected. Sheep were then fitted with satellite GPS/NHF radio collars (Telonics Inc., Mesa, AZ). GPS collars were TGW-3580 store-on-board units with ARGOS satellite uplink capability. Maximum capture processing time was approximately $20 \mathrm{~min}$. Location data were recorded by the collars 3 times per day at 05:00, 12:00, and 16:00 (Pacific Standard Time). Collars were fitted with an automatic breakaway collar release and mortality sensor. GPS location data were uplinked to ARGOS satellites every 2 days. All capture operations were approved by and 


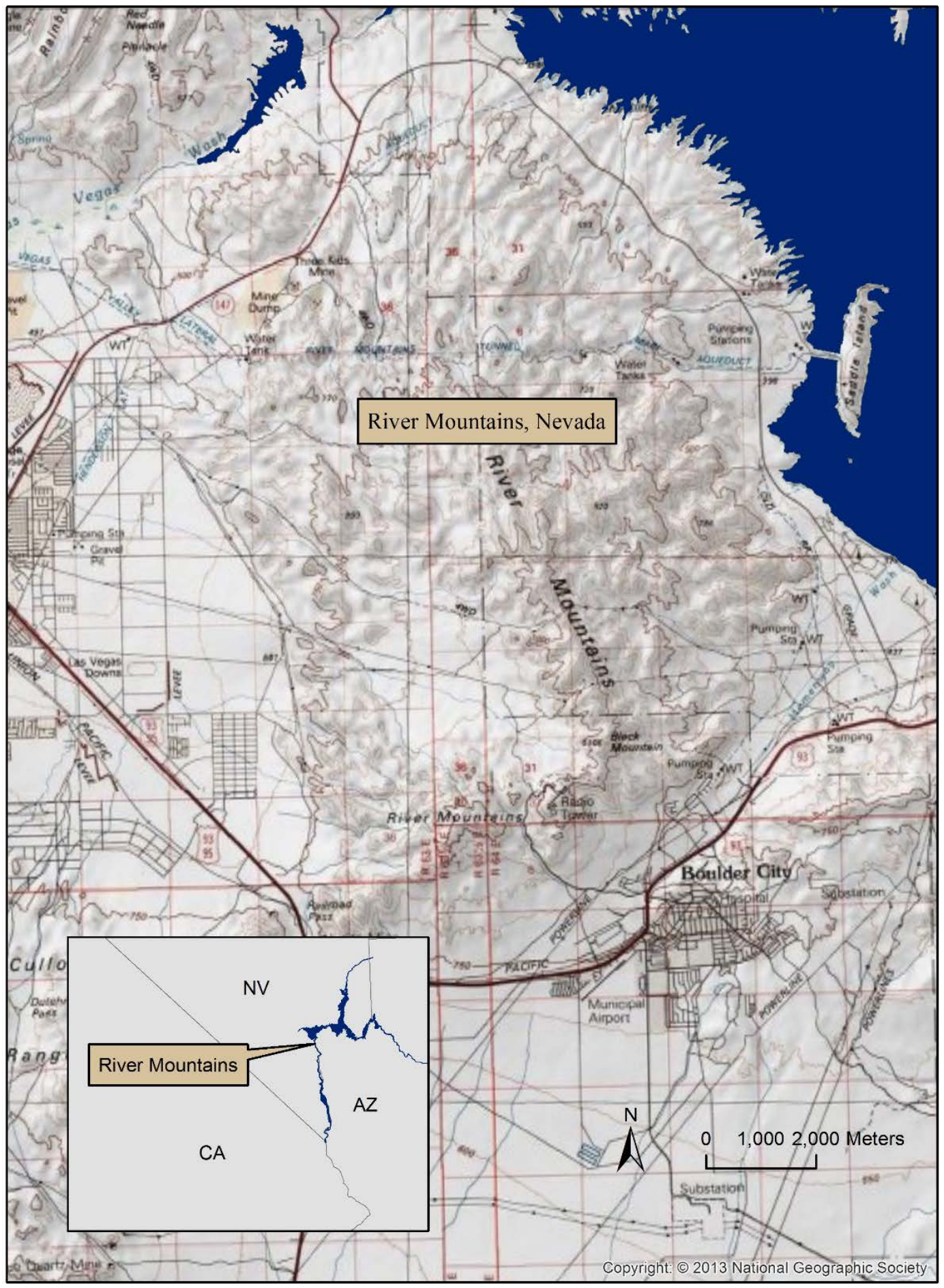

Fig. 1. Location and map of the River Mountains, Nevada, 2005. 
carried out in strict accordance with guidelines of the University of Nevada, Las Vegas, Institutional Animal Care and Use Committee.

\section{Habitat Modeling and Analyses}

Animal locations were separated by gender before analysis. We used several criteria known to successfully predict desert bighorn sheep habitat across the Southwest to create our candidate resource selection function (RSF) models: percentage slopes (Bleich et al. 1997, Singer et al. 2000b, Turner et al. 2004), vector ruggedness measures (VRM) (Sappington et al. 2007), distance to water sources (Bleich 1990, Rosenstock et al. 1999), and distance to disturbed or attractive areas (Papouchis et al. 2001, Longshore et al. 2009). The VRM is less correlated with slope than other terrain ruggedness metrics, making it more useful for bighorn sheep habitat analysis (Sappington et al. 2007). The VRM was calculated by first measuring the 3dimensional angles within each $10 \times 10$-m cell covering the study area, then, for each cell, quantifying the variation in terrain angles and aspect across a $3 \times 3-\mathrm{m}$ moving window (grid of 9 cells centered on the focal cell). These continuous variables were calculated with a GIS (ArcMap 10.2, Esri, Redlands, CA) and standardized relative to the population mean of the entire data set including random points (J. Yee, USGS statistician, personal communication). The slope and VRM variables were weakly correlated and therefore treated as independent variables $(r=0.178)$. Water sources were available year-round and were categorized as municipal and nonmunicipal types. Nonmunicipal water sources were wildlife guzzlers specifically designed for bighorn sheep. We further categorized municipal water sources as either a municipal park or a golf course (which has open water), then measured the distances from each sheep location to all sources by use of a GIS (see subsequent area identification section). Because no collared females used or approached the golf course, we did not use this variable within the female model selection process. Three 4-month season categories were based on weather patterns and bighorn biology: January-April included the lambing period, relatively greater rainfall, and relatively greater forage availability; May-August included the mating season, relatively poor forage, and high temperatures; and September-December included cooler temperatures and winter forage availability (Monson and Sumner 1981, Shackleton 1985, Rubin et al. 2000).

To determine how animals were recently using the landscape, location data and an equal number of random points were analyzed using binary logistic regression to produce log-likelihood values which were then entered into an Akaike information criterion model selection process adjusted for small populations $\left(\mathrm{AIC}_{c}\right)$ (Burnham and Anderson 2002). Although use of logistic regression for use-availability data produces RSF values that are simply proportional to animal probability of occurrence, this type of analysis yields robust and valid estimates of habitat selection (Boyce and McDonald 1999, Johnson et al. 2006). We used the Geospatial Modeling Environment software (version 7.4.0, Spatial Ecology LLC). $\mathrm{AIC}_{c}$ candidate model sets were chosen to determine aspects of seasonal habitat use, the potential impacts of human activities, and the specific impacts of manmade sources of water and forage. Seasonal differences in habitat use and human activities were identified by comparing and contrasting the standardized coefficients (beta coefficients) of the season by variable interaction terms. The coefficients of these interactions are a measure of the strength of the effect of the independent variable on the dependent variable and allow relative ease of comparison among variables when variables are normally distributed (Sokal and Rohlf 1998). We recognize that there are some disadvantages of using a unitless (standardized) measure; however, because our goal was comparative, we believe the standardized coefficient approach is the most appropriate. Furthermore, using logistic regression beta coefficients allowed us to specifically measure the strength and direction (positive or negative) of the effects of season and human activities on habitat use (as opposed to using AIC parameter weights, which are a measure of predictor variable "importance" [Burnham and Anderson 2002]). Model performance was determined using area under the curve (AUC) values derived by a receiver operating characteristic (ROC) analysis. (Hanley and McNeil 1982, Manel et al. 2001).

Identifying Areas of Disturbance and Attraction, and Amount of Bighorn Habitat

We define attractive areas as those areas with forage and water resources perceived by 
animals as highly beneficial relative to the surrounding natural habitat. Disturbed areas are defined as those perceived to have greater risks of disturbance from human activities. Natural areas are defined as those occurring without specific attractive resources (e.g., water sources) or disturbed areas. We used GPS-collared bighorn sheep locations, remote sensing maps (U.S. Geological Survey), and ground surveys to identify 4 major areas of potential disturbance or attraction within the study area: a mountain bike park (disturbed area) on the south side of the range, a golf course (attractive area) on the southwest side, and a residential housing community (disturbed area) and a municipal park (attractive area) on the southeast side (Fig. 2). Total habitat area potentially affected by the mountain bike park and the suburban area was determined by placing a 400-m buffer around existing bike trails and roads (Papouchis et al. 2001). The buffer was adjusted for local physiography using a GIS line-of-sight (from the trail/road) program, meaning that only those areas within sight of the trail/road were considered potentially disturbed. We did not use a buffer for the 2 attractive areas. Although there is a bicycle/walking trail that generally follows the perimeter of the River Mountains, this trail was not completed during the study period and therefore was not included.

Perceived risk varied across the study area. The northern central range was largely undisturbed except for a private water treatment facility in the central eastern area at relatively low elevation. Human activities were primarily in the southern edge of the range where, from west to east, the golf course, mountain bike park, residential area, and municipal park were located (Fig. 2). The isolation of the bighorn population from other populations is almost complete because animals must cross a major highway to get to any adjacent range in addition to coping with the close proximity of Lake Mead and urban areas. Mountain lions, bighorn sheep's primary predator, do not occur within the River Mountains due to the range's lack of a deer population, small size, and isolation from other ranges (P. Cummings, NDOW bighorn biologist, personal communication). Because of these factors, we believe the areas identified constitute the primary sources of perceived risk within the River Mountains.
To measure the habitat potentially affected within these areas, we entered the highest AICrated model within the September-December season into the raster calculator of the GIS. We believed this season to be the most appropriate as it was the period of maximum range extent for bighorn sheep (this study, unpublished data). The raster calculator generated a map of relative probability (rescaled to $0-1$ ) of desert bighorn sheep occurrence, also known as resource selection functions (RSF), across the study area (Boyce 2006). To quantify suitable habitat, we added our bighorn sheep locations to this RSF map to determine at which range of RSF values $>95 \%$ of all bighorn sheep locations occurred (Boyce and McDonald 1999). We found that $>95 \%$ of locations occurred in areas within the top $40 \%$ of RSF values, and we therefore defined these areas as suitable bighorn habitat. We then measured suitable habitat within each of our defined areas that is potentially affected by human activities.

We estimated the proportion of the River Mountain sheep population using the municipal park by taking weekly counts of sheep in the park from 2007 to 2012. Although these counts started 2 years later than the study period, we believe they closely represent the long-term pattern of park use (P. Cummings, NDOW biologist, personal communication). We then divided the maximum number observed by the 2007-2012 population estimates obtained from NDOW to calculate the proportion.

\section{Comparison of Historic to Recent Habitat Use}

Our goal was to determine how areas of disturbance and attraction, which were created after the historic period, may have affected habitat use in the recent period. Given these goals, genders were pooled for this analysis. Our data set consisted of 266 historic bighorn sheep locations collected by helicopter surveys within the River Mountains from 1970 to 1978 (October of each year), 266 recent locations randomly chosen from satellite GPS-collar data (described above) taken in October of 2003 and 2004, and 532 random points. We measured the habitat variables underlying each of these locations with a GIS (Table 1). Correlation between slope and VRM was low $r=0.136)$, therefore we treated those variables as independent. Ten candidate logistic 


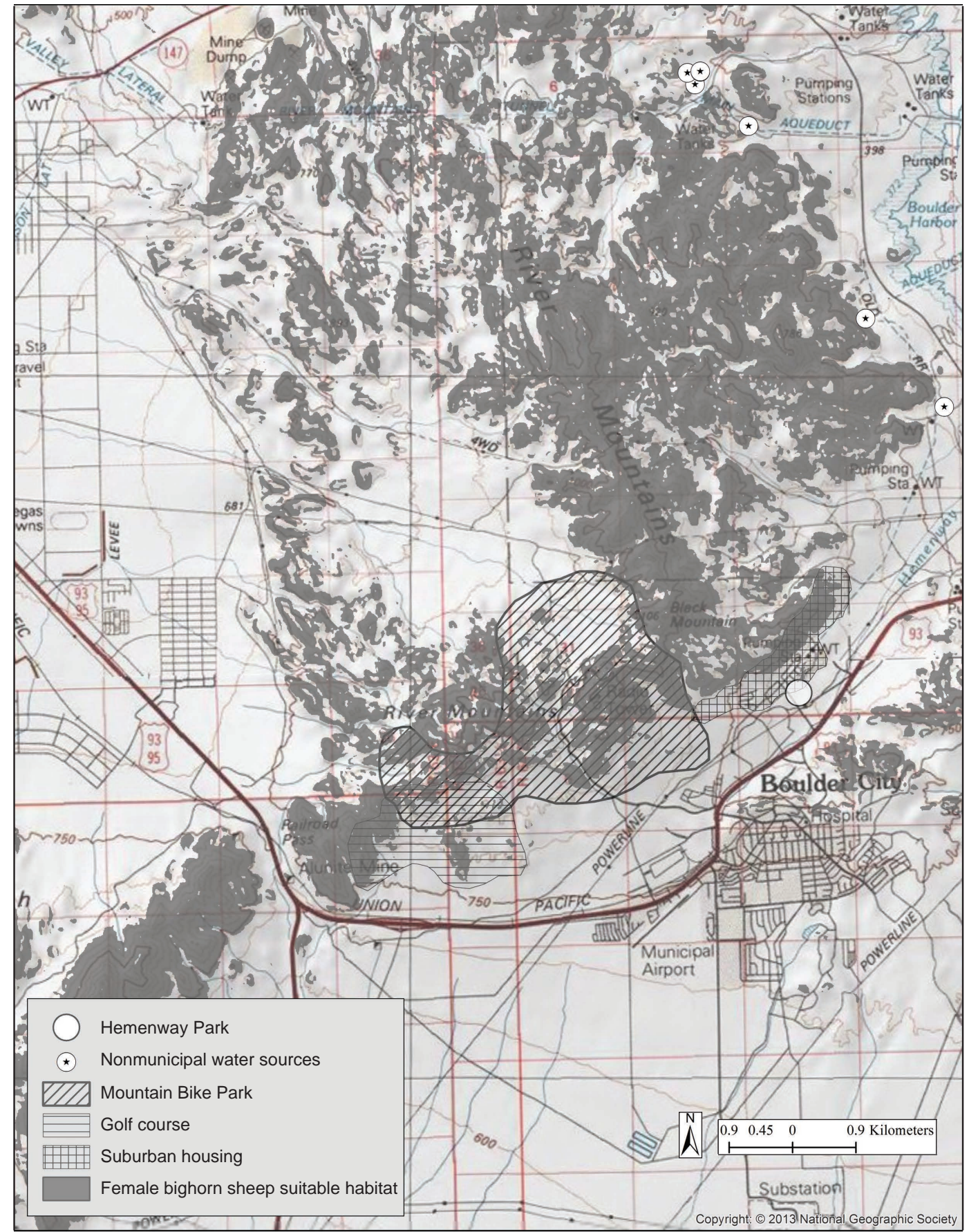

Fig. 2. Water sources, Hemenway Park, and areas of suitable bighorn sheep habitat potentially affected by anthropogenic activities. River Mountains, Nevada, 2005.

regression models were designed to test for differences between historic and recent time periods by contrasting the 2 sets of use locations within each model. We specifically compared and contrasted the standardized coefficients (beta coefficients) of the time-by-variable 
TABLE 1. Descriptive statistics of habitat variables used by male and female desert bighorn sheep. Distances are given in kilometers.

\begin{tabular}{|c|c|c|c|c|}
\hline Variables & Gender & Mean & SD & Range \\
\hline Distance to municipal water ${ }^{\mathrm{a}}$ & $\mathrm{F}$ & 5.16 & 2.30 & $0.0-10.83$ \\
\hline Distance to municipal water & M & 3.95 & 2.64 & $0.0-10.72$ \\
\hline Distance to nonmunicipal water & $\mathrm{F}$ & 3.80 & 1.63 & $32-7.73$ \\
\hline Distance to nonmunicipal water & M & 5.72 & 2.99 & $254-11.32$ \\
\hline Distance to bike trails & $\mathrm{F}$ & 3.90 & 1.94 & $0-8.74$ \\
\hline Distance to bike trails & M & 3.14 & 1.52 & $0-7.91$ \\
\hline Distance to golf course & $\mathrm{F}$ & 7.09 & 2.05 & $1.2-12.7$ \\
\hline Distance to golf course & M & 4.82 & 3.11 & $0-11.82$ \\
\hline Slope percentage & $\mathrm{F}$ & 41.7 & 20.8 & $1-139.1$ \\
\hline Slope percentage & M & 35.0 & 16.5 & $1.5-103.2$ \\
\hline Vector ruggedness measure & $\mathrm{F}$ & 0.02 & 0.01 & $0-0.16$ \\
\hline Vector ruggedness measure & M & 0.01 & 0.01 & $0-0.09$ \\
\hline
\end{tabular}

aMunicipal water was available in both municipal park and golf course areas.

interactions. Significant differences in coefficient values between the historic and recent time periods represent a quantifiable measure of how habitat use may have changed between time periods (Manly et al. 2002). Performance of the highest $\mathrm{AIC}_{c}$-ranked model was evaluated with the AUC derived from a ROC analysis. We analyzed daily precipitation levels (Nevada Remote Automated Weather Station, Boulder City) between time periods with an ANOVA to evaluate any differences in rainfall which may have contributed to our results.

\section{RESUlTS}

\section{Bighorn Sheep Habitat Use}

The relative probability of female occurrence in a habitat was best predicted by using all variables and seasonal interactions $\left(\chi^{2}=\right.$ $5455.4, P<0.001)$. AUC model performance for females was 0.921 (95\% CI 0.915-0.928) (Tables 2, 3). There were 2 plausible model alternatives for males: the highest-ranked model included all variables and interactions, while in the second model the effect of ruggedness was omitted. For competing model candidates $\left(\Delta \mathrm{AIC}_{c}<2.0\right)$, we used AIC model weight and parsimony to choose the highestranking model $\left(\chi^{2}=910.5, P<0.001\right)$. AUC model performance for males was 0.854 (95\% CI 0.836-0.872). Although competing models may be averaged, our preference for using model coefficients to interpret variable strength precludes this approach (Burnham and Anderson 2002). Both males and females used undisturbed and disturbed areas differently. Females used steeper slopes and more rugged areas, were more likely to use the municipal park, and were less likely to use nonmunicipal water than males (Tables 4, 5). Collared females did not use or approach the golf course. When analyzed over the entire 2 -year study period, beta coefficient and odds ratios indicated that female occurrence decreased by $19 \%$ and $23 \%$ for every $1 \mathrm{~km}$ increase in distance from the municipal park and nonmunicipal water sources, respectively. Seasonally, females were closer to nonmunicipal water sources during the May-August and September-December seasons than the JanuaryApril season (Table 4). Female sheep occurrence decreased by $10 \%$ for every $1 \mathrm{~km}$ increase away from municipal water during the May-August seasons relative to JanuaryApril. Females used steeper, more rugged slopes during January-April than other seasons (Table 4).

Males used lower slopes than females, avoided rugged areas, and were more likely to use the nonmunicipal water sources and the golf course than the municipal park (Table 5). Males were strongly attracted to the golf course during the summer months and less but still significantly so during the September-December months. Over the entire study time period, male occurrence decreased by $25 \%$ and $32 \%$ for every $1 \mathrm{~km}$ increase away from the golf course and nonurban water sources, respectively (Table 5). Male occurrence decreased by $25 \%$ for every $1 \mathrm{~km}$ increase away from the golf course during the May-August season relative to the JanuaryApril season. Males demonstrated no seasonal change of habitat use in terms of slope or ruggedness. 

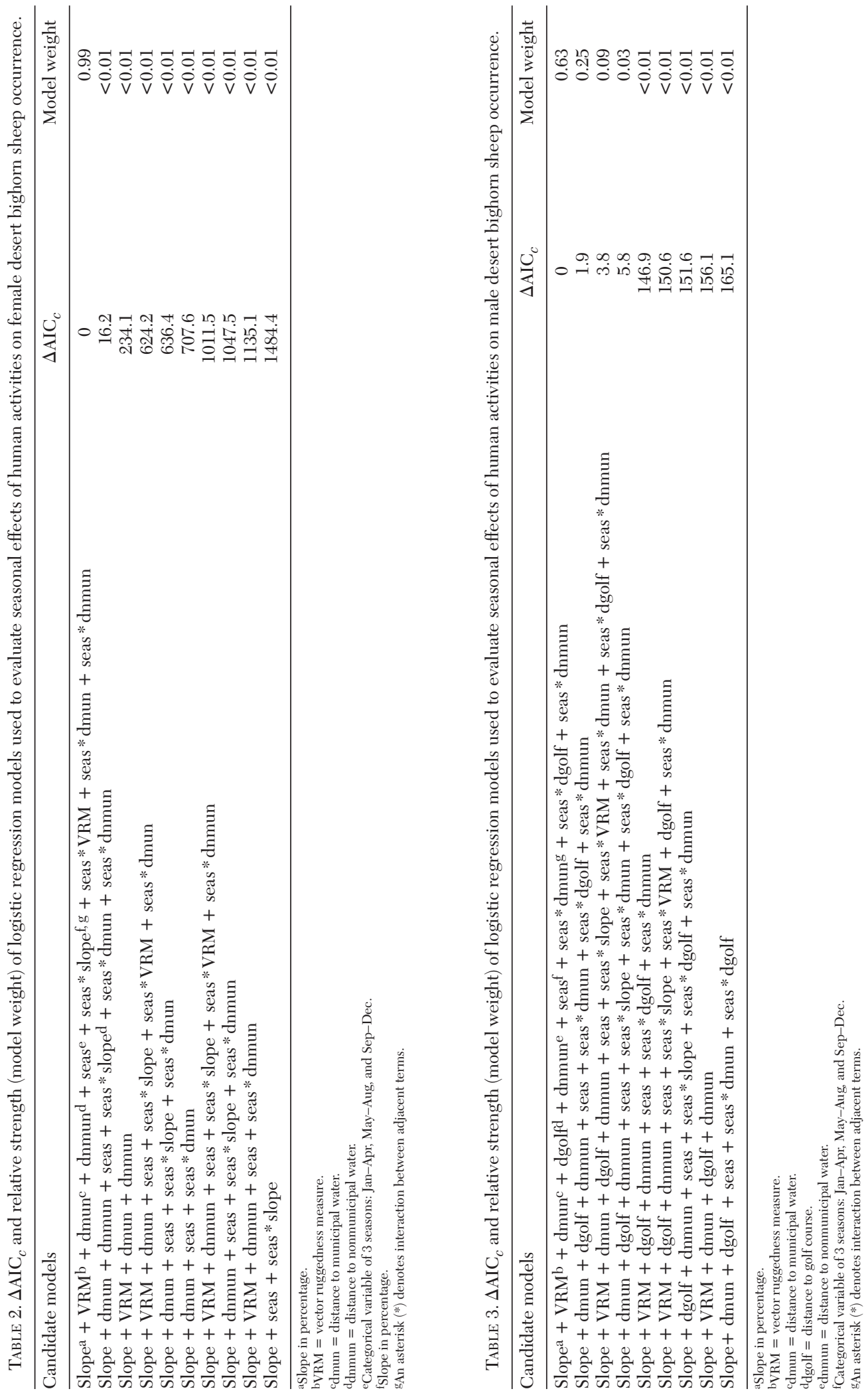
TABLE 4. Model variable (standardized) beta coefficients, standard deviations (SD), and change in probability of occurrence values (odds ratios) for female bighorn sheep.

\begin{tabular}{|c|c|c|c|c|c|}
\hline Variables & Season $^{\mathrm{a}}$ & Beta & $\mathrm{SD}$ & Prob.b & $P$ \\
\hline Slope percentage & All & 1.815 & 14.1 & 514.1 & $<0.001$ \\
\hline Vector ruggedness measure & All & 0.037 & 0.008 & 270.0 & 0.388 \\
\hline $\mathrm{D}^{\mathrm{c}}$ to nonurban water & All & -0.832 & 2446.8 & -56.4 & $<0.001$ \\
\hline D to municipal park & All & -0.911 & 3102.7 & -59.7 & $<0.001$ \\
\hline D to nonurban water $*$ season $\mathrm{d}$ & 1 & 0.336 & 2446.8 & 39.9 & $<0.001$ \\
\hline D to nonurban water * season & 2 & -0.074 & 2446.8 & -7.1 & 0.420 \\
\hline D to municipal park * season & 1 & 0.596 & 3102.7 & 81.4 & $<0.001$ \\
\hline D to municipal park * season & 2 & -0.365 & 3102.7 & -30.5 & 0.001 \\
\hline Slope $*$ season & 1 & 0.621 & 20.8 & 86.0 & $<0.001$ \\
\hline Slope * season & 2 & 0.035 & 20.8 & 3.5 & 0.784 \\
\hline Ruggedness * season & 1 & 0.381 & 0.008 & 46.3 & $<0.001$ \\
\hline Ruggedness * season & 2 & -0.071 & 0.008 & -6.9 & 0.499 \\
\hline
\end{tabular}

aSeason 1 = Jan-Apr, season 2 = May-Aug, season 3 = Sept-Dec (reference category: seasonal values are relative to season 3).

bProb. = change in percent probability of bighorn sheep occurrence for every 1 standard deviation increase in the independent variable.

$\mathrm{c} \mathrm{D}=$ distance in meters.

$\mathrm{d}_{\text {An }}$ asterisk $(*)$ denotes interaction between adjacent terms.

TABLE 5. Model variable (standardized) beta coefficients, standard deviations (SD), and change in probability of occurrence values (odds ratio) for male bighorn sheep.

\begin{tabular}{lcccrr}
\hline Variables & Season $^{\mathrm{a}}$ & Beta & SD & Prob. ${ }^{\text {b }}$ & $P$ \\
\hline Slope percentage & All & 1.164 & 11.6 & 218.9 & $<0.001$ \\
Vector ruggedness measure & All & -0.083 & 0.006 & -8.0 & 0.049 \\
D $^{\mathrm{c}}$ to golf course & All & -3.761 & 3867.5 & -97.7 & $<0.001$ \\
D to nonurban water & All & -2.176 & 2817.5 & -88.7 & $<0.001$ \\
D to municipal park & All & 1.774 & 3070.9 & 489.4 & $<0.001$ \\
D to golf course * season & 1 & 1.13 & 3867.5 & 209.5 & 0.020 \\
D to nonurban water * season & 1 & 0.521 & 2817.5 & 68.3 & $<0.001$ \\
D to municipal park * season & 1 & -0.876 & 3070.9 & -58.4 & $<0.001$ \\
D to golf course * season & 2 & -4.108 & 3867.5 & -98.4 & 0.024 \\
D to nonurban water * season & 2 & -2.806 & 2817.5 & -94.0 & $<0.001$ \\
D to municipal park * season & 2 & 2.380 & 3070.9 & 980.4 & $<0.001$
\end{tabular}

aSeason 1 = Jan-Apr, season 2 = May-Aug, season 3 = Sep-Dec (reference category: seasonal values are relative to season 3).

bProb $=$ change in percent probability of bighorn sheep occurrence for every 1 standard deviation increase in the independent variable.

$\mathrm{c} D=$ distance in meters.

dAn asterisk $(*)$ denotes interaction between adjacent terms.

\section{Area Affected by Human Activity and Proportion of Population Using the Municipal Park}

Because females generally use steeper habitat of a lesser range than males, we used the female-based model to represent a conservative estimate of habitat affected by human activity. Our highest-ranked recent habitat use model (see previous section), which defines suitable habitat (Fig. 2), predicted approximately $86.8 \mathrm{~km}^{2}$ of potential habitat available for desert bighorn sheep before considering potential impacts due to human activity. This habitat was relatively contiguous except for an area characterized by lower slopes in the west central part of the range. We found that approximately 1500 ha $(16.9 \%)$ of the available suitable habitat was within $400 \mathrm{~m}$ of human activities, the largest potentially disturbed area being the mountain bike park (1170 ha, 13.5\%) followed by the suburban area (193.1 ha). The largest attractive area was the golf course (minus overlap of bike area $=134.2 \mathrm{ha}$ ) (Fig. 3). Our counts of up to 84 animals using the municipal park (monthly mean $=32.3$, SD 26.9) represented approximately $30 \%-40 \%$ of the total estimated population within the River Mountains, Nevada.

\section{Comparison of Historic to Recent Habitat Use}

We contrasted historic and recent habitat use data within 10 candidate models. Two candidate models contained reasonable levels of support for predicting desert bighorn sheep occurrence (Table 6). The Akaike model weight of the highest-rated model (the likelihood of the model given the data) was $0.71\left(\chi^{2}=\right.$ 178.3, $P<0.001$ ) (Burnham and Anderson 


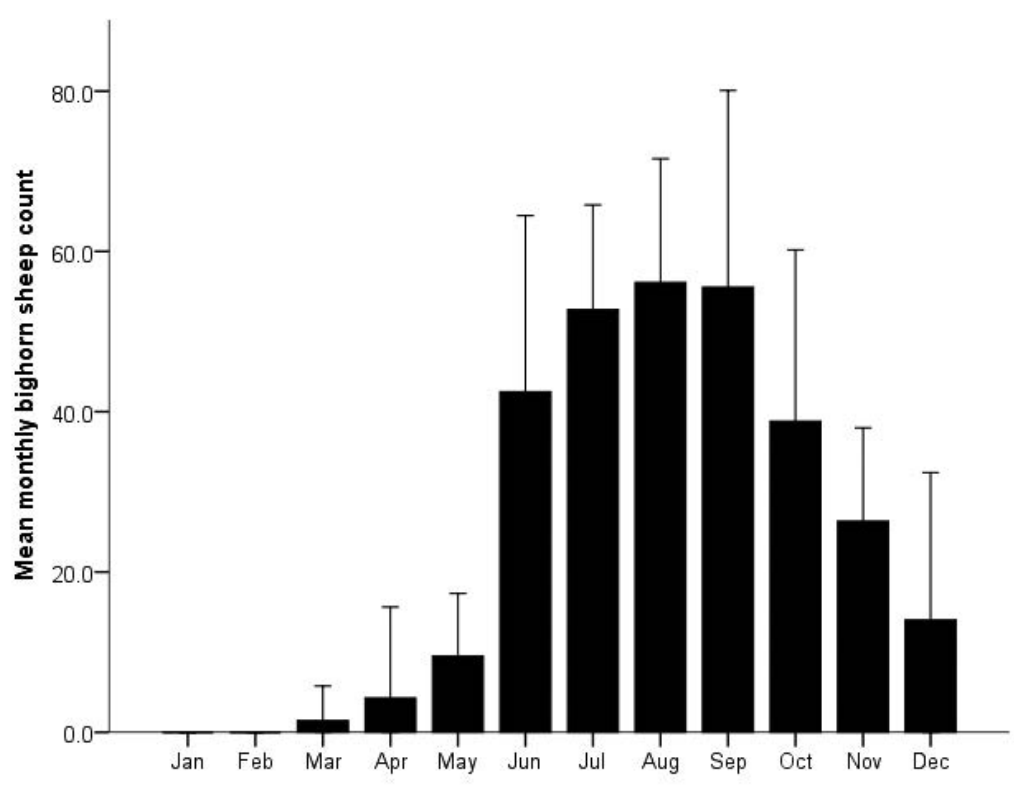

Fig. 3. Mean monthly totals of desert bighorn sheep using Hemenway Municipal Park near the River Mountains, Nevada, 2007-2012.

2002). AUC of the highest-rated model was 0.725 (95\% CI 0.694-0.754). All 3 anthropogenic variables (bike park, municipal water and forage sources, and nonmunicipal water sources) contributed to the highest-ranked models. Probability of bighorn sheep increased as distance from the bike trail area increased during both time periods; however, this effect was greater in the recent period than in the historical period (Table 7). We found no interaction between time period and nonmunicipal water source, indicating no difference between historic and recent use. As expected, recent period animals were more likely to be found closer to municipal water sources than animals from the historic time period. Probability of occurrence increased as slope increased within the historic time period, and increased as slope decreased in the recent period, likely due to increased use of the municipal areas that are on low slopes (Table 7). We found no difference in precipitation levels between the 2 time periods $(P=$ $0.222, F=1.505, \mathrm{df}=1$ ).

\section{Discussion}

Our study found that desert bighorn sheep selected habitat as a function of levels of anthropogenic disturbance and attractiveness of local resources. Human activities may result in sheep avoidance of (Bates and Workman 1983, Rubin et al. 2002) or attraction to (Adams 1994) disturbed areas. Importantly, we found that interactions between attractiveness and disturbance factors occur both seasonally and between time periods for both sexes. Animals will tolerate disturbance until the perceived risk outweighs the perceived gain of staying in the area (Frid and Dill 2002), and sheep may increase their tolerance for disturbance in areas that have a strong attractive resource (Gill et al. 2001, Rubin et al. 2002). We found that at strongly attractive resource areas desert bighorn sheep were willing to tolerate nearby low-intensity and predictable human activities (i.e., use of residential and municipal parks). However, animals almost completely abandoned less attractive but otherwise suitable habitat when disturbed by high-intensity, unpredictable mountain bike use. We recognize that our relatively low sample size and the fact that animals may use behavioral mechanisms (Mooring et al. 2004) to mitigate risks in ways that are unmeasured in this study weaken our results. We believe, however, that the consistency of our findings across genders and seasons and between historic and recent time periods, as well as the physical isolation and the lack of major 


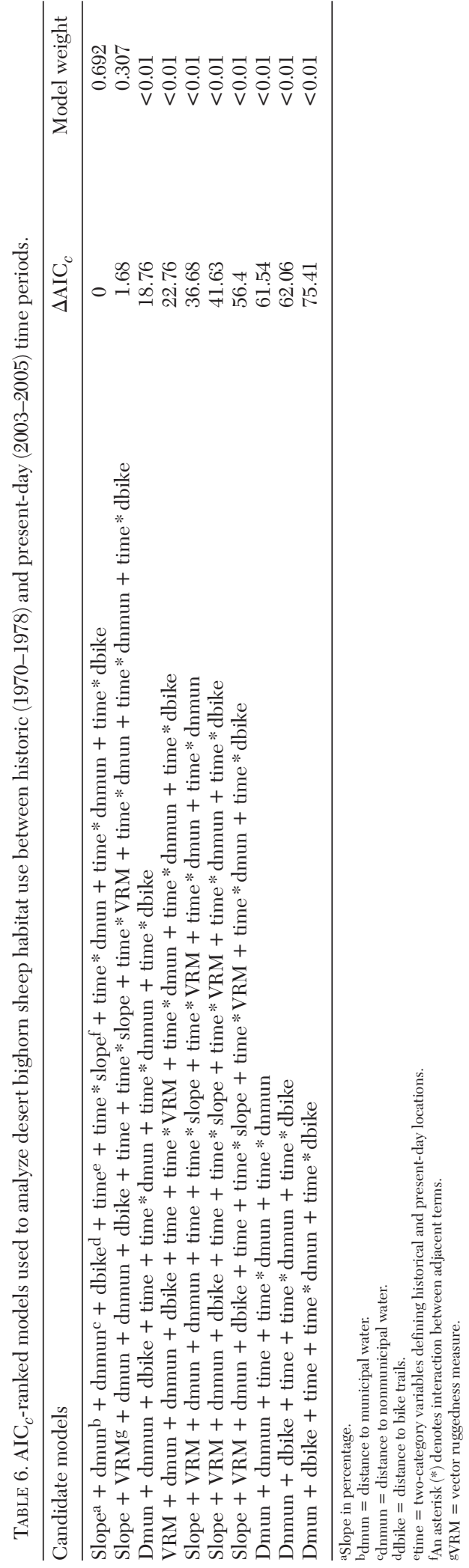

predators, strongly suggests that our results are substantially due to anthropogenic changes in the River Mountains.

\section{Habitat Use and Effects of Attractive and Disturbed areas}

Under the risk-disturbance hypothesis, bighorn sheep must trade off between perceived risk and resource richness in order to approach and inhabit the municipal park and golf course, with the associated increases in forage and water resources (Gill et al. 1996, Frid and Dill 2002). We found that many animals had clearly accepted this risk, demonstrating a tolerance for the approximately 0.5 $\mathrm{km}$ of travel through suburban housing necessary to access the municipal park. They also tolerated human activity to access and maintain a close proximity to the golf course. Male and female bighorn sheep, with their different foraging strategies and tolerance levels (Bleich et al. 1997), should respond differently to similar disturbances (Berger et al. 1983, Gill et al. 2001). Collared males used both the municipal park and golf course and were less likely to return to natural areas than females, displaying a greater tolerance to humans than that of females by remaining near municipal areas that have an attractive forage source regardless of season (Table 5). Collared females did not use the golf course, which was accessible from a low-lying (less steep) area in the north and through the mountain bike park. Males are more likely to travel through less steep areas (Bleich et al. 1997), which may explain the female preference for the municipal park which was much closer to steep areas. For females and their young, the birthing season (January-March) increases the risk of predation (Geist 1971, Festa-Bianchet 1988), and the increased availability of forage was not enough to override the antipredator response of moving to steeper slopes during this time of year (Table 4).

Human developments and activities decreased the availability of suitable habitat for the River Mountain sheep population. We found a loss or avoidance of approximately $17 \%$ of desert bighorn sheep habitat. The large majority of this lost or avoided area, which cannot be explained by differences in suitability, was apparently due to creation of the mountain bike park. Our study suggests that certain areas within the River Mountains 
TABLE 7. Time period by habitat predictor variable coefficients and differences in coefficient values between present-day (October 2003-2005) and historic time (October 1970-1978) periods.

\begin{tabular}{|c|c|c|c|c|c|}
\hline Variable & Beta $^{\mathrm{a}}$ & $\mathrm{SE}$ & Wald & Difference $^{b}$ & $P$ \\
\hline Historic time $* \mathrm{D}^{\mathrm{c}}$ to bike trails $\mathrm{d}$ & -1.686 & 0.41 & 29.72 & 2.22 & $<0.001$ \\
\hline Present time $* \mathrm{D}$ to bike trails & 0.530 & 0.26 & 3.90 & & \\
\hline Historic time ${ }^{*} \mathrm{D}$ to nonmunicipal water & -0.057 & 0.26 & 20.41 & 0.70 & $<0.001$ \\
\hline Present time $* \mathrm{D}$ to nonmunicipal water & -0.757 & 0.15 & 49.39 & & \\
\hline Historic time $* \mathrm{D}$ to municipal water & 1.795 & 0.42 & 39.47 & 2.67 & $<0.001$ \\
\hline Present time * D to municipal water & -0.873 & 0.26 & 11.54 & & \\
\hline Historic time * Percentage slope & 0.453 & 0.14 & 8.20 & 0.41 & 0.004 \\
\hline Present time * Percentage slope & 0.081 & 0.11 & 0.15 & & \\
\hline
\end{tabular}

abeta $=$ coefficient values from a binary logistic regression

bDifference $=$ the absolute difference between historic and present-day beta values

$\mathrm{c} D=$ distance.

$\mathrm{d}_{\text {An }}$ asterisk (*) denotes interaction between adjacent terms.

have been abandoned or avoided by part of the bighorn sheep population due to mountain bike activities. Certainly other factors may have contributed to these findings, and animals may have been avoiding this area only during our October observations. We suggest, however, that this is unlikely given the apparent avoidance of the area over a 2 -year period (Fig. 4) and the fact that habitat within the bike park is suitable for bighorn sheep (outside of the bike trails themselves). Animals forced out of habitat may be able to occupy similar, adjacent habitat if it is available (Gill et al. 2001). However, the River Mountains are strongly isolated by urbanization, suitable bighorn sheep habitat is used extensively (Fig. 4), and losses within this finite area cannot be replaced by the expansion or shifting of home ranges. A shift away from suitable habitat under these conditions may increase fitness costs (Gill et al. 2001).

\section{Comparison of Historic to Recent Habitat Use}

Our study suggests that the anthropogenic activities of adding parks, golf courses, and mountain bike areas have altered habitat use patterns between historic and recent time periods. Other authors have shown that ungulates alter habitat use in response to recreation activities (Papouchis et al. 2001, Manor and Saltz 2005), development (Johnson et al. 2002), and disturbance (Stankowich 2008). Our study both supports these previous findings and provides evidence that habitat alteration caused by human activities may have long-term impacts for desert bighorn sheep. Municipal water sources and grass-covered areas were clearly acting as attractors to bighorn sheep of both sexes within the recent period, altering habitat use of an estimated $40 \%$ of the population based on the number of sheep observed at the park (Fig. 3). Sheep were consistently relying on artificially provided sources of food and water in the recent period and may therefore be less likely to follow historic movement patterns and diet restrictions according to climate-based seasonal demands (Leslie and Douglas 1980). This disruption in movement patterns and tolerance to human activities near and at the park may have created artificially greater densities of sheep than those found in natural areas (personal observation). Greater local densities may result in increased disease transmission (Monello et al. 2001), which can limit bighorn population growth (Cassirer and Sinclair 2007).

In the recent period, collared bighorn sheep almost completely avoided the bike park area relative to the historic period. Although there was some detectable avoidance behavior of the bike park area in the historic period likely due to off-road recreation activities, the effect was significantly greater in the recent period (Table 7). This effect remained even during the summer months when bike park attendance was relatively low, suggesting sheep intolerance to even low levels of mountain bike activity. Although avoidance may not necessarily signify a loss of population-level fitness (Gill et al. 2001), habitat loss may be a concern if animals have no adjacent alternatives.

Our study implies that recreation activities, specifically mountain biking, may have longterm negative impacts on the ability of desert bighorn sheep to use native habitat. If habitat availability in isolated areas is reduced, the long-term viability of populations in those 


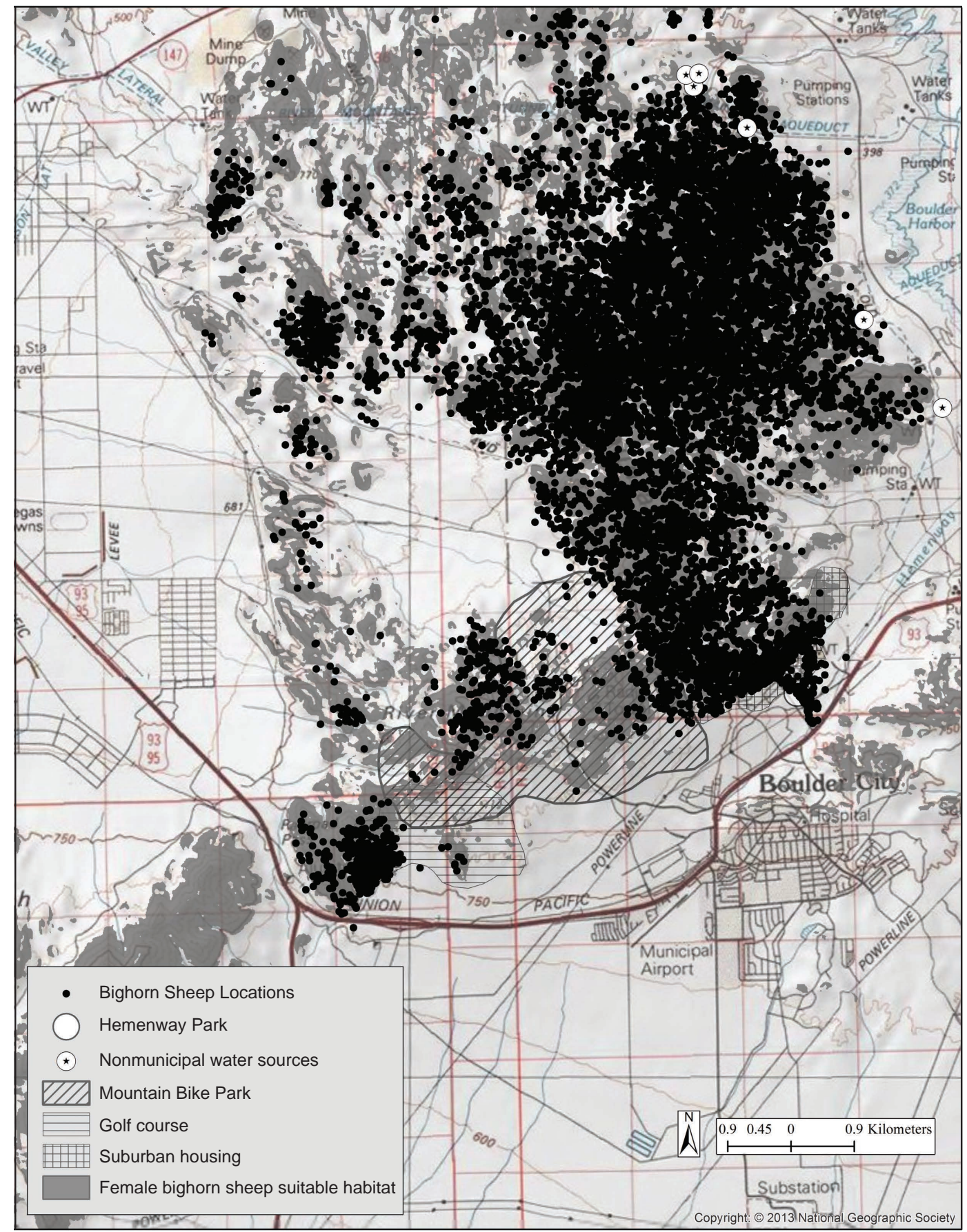

Fig. 4. Desert bighorn ram and ewe locations showing avoidance of areas underlying bike trails within the River Mountains, Nevada, 2003-2005.

areas may also diminish. The overlapping political jurisdictions over the River Mountains demand coordination from federal, state, and local officials to mitigate these potential effects. Education of the public, especially users of these habitats, could help mitigate the 
impacts of mountain biking on desert bighorn sheep habitat use. We therefore recommend that an education effort be developed by the responsible land managers. Instigating a longterm examination of mountain bike movements in coordination with response observations of collared animals may allow specific hypotheses to be tested, including the effects of mountain bike restriction in certain areas deemed critical to bighorn sheep survival. Continuing research that draws causal links between human activities, sheep behavior, and long-term fitness consequences within the River Mountain bighorn sheep herd may provide useful information to resource managers.

\section{ACKNOWLEDGMENTS}

We sincerely thank the National Park Service, the Lake Mead National Recreation Area, the Nevada Department of Wildlife, and the Boulder City Council for their assistance in this study. We also thank Dr. Julie Yee of the USGS for statistical advice, as well as Patrick Cummings of the Nevada Department of Wildlife and Ross Haley of the National Park Service for their input and expertise. The use of trade, product, or firm names in this product is for descriptive purposes only and does not imply endorsement by the U.S. government.

\section{Literature Cited}

ADAms, L.W. 1994. Urban wildlife habitat. University of Minnesota Press, Minneapolis, MN.

Altmann, J. 1974. Observational study of behavior: sampling methods. Behaviour 49:227-266.

Bates, J.W., and G.W. Workman. 1983. Desert bighorn sheep habitat utilization in Canyonlands National Park. Desert Bighorn Council Transactions 27: $25-28$.

Bender, D.J., T.A. Contreras, and L. Fahrig. 1998. Habitat loss and population decline: a meta-analysis of the patch size effect. Ecology 79:517-533.

Berger, J., D. Daneke, J. Johnson, and S.H. Berwick. 1983. Pronghorn foraging economy and predator avoidance in a desert ecosystem; implications for the conservation of large mammalian herbivores. Biological Conservation 25:193-208.

Beyer, H.L., R. Ung, D.L. Murray, and M. Fortin. 2013. Functional responses, seasonal variation and thresholds in behavioral responses of moose to road density. Journal of Applied Ecology 50:286-294.

BLEICH, V.C. 1990. Desert dwelling mountain sheep: conservation implications of a naturally fragmented population. Conservation Biology 4:383-390.

Bleich, V.C., R.T. Bowyer, and J.D. Wehausen. 1997. Sexual segregation in mountain sheep: resources or predation. Wildlife Monographs 134:1-50.
Boyce, M.S. 2006. Scale for resource selection functions. Diversity and Distributions 12:269-276.

Boyce, M.S., AND L.L. MCDonaLD. 1999. Relating populations to habitat using resource selection functions. Trends in Ecology and Evolution 14:268-272.

Burnham, K.P., and D.R. Anderson. 2002. Model selection and multimodel inference: a practical information theoretic approach. Springer Press, New York, NY.

Cassirer, E.F., and A.R.E. Sinclair. 2007. Dynamics of pneumonia in a bighorn sheep population. Journal of Wildlife Management 71:1080-1088.

Cooper, S.M., M.K. Owens, R.F. CoOper, and T.F. GinNETT. 2006. Effect of supplemental feeding on spatial distribution and browse utilization by whitetailed deer in a semi-arid rangeland. Journal of Arid Environments 66:716-726.

DeForge, J.A. 1981. Stress: changing environments and the effects on desert bighorn sheep. Desert Bighorn Council Transactions 25:15-16.

Dyer, S.J., J.P. O’Niell, S.M. Wasel, and S. Boutin. 2001. Avoidance of industrial development by woodland caribou. Journal of Wildlife Management 65: 531-542.

Etchberger, R.C., P.R. Krausman, and R. Mazaika. 1989. Mountain sheep habitat characteristics in the Pusch Range Wilderness, Arizona (USA). Journal of Wildlife Management 53:902-907.

Festa-Bianchet, M. 1988. Seasonal range selection in bighorn sheep: conflicts between forage quality, forage quantity, and predator avoidance. Oecologia 75:580-586.

Frid, A., AND L. DiLl. 2002. Human-caused disturbance stimuli as a form of predation risk. Conservation Ecology 6(1):11.

GEIST, V. 1971. Mountain sheep: a study in behavior and evolution. University of Chicago Press, Chicago, IL.

Gill, J.A., K. Norris, and W.J. Sutherland. 2001. Why behavioral responses may not reflect the population consequences of human disturbance. Biological Conservation 97:265-268.

Gill, J.A., W.J. Sutherland, And A.R. Watkinson. 1996. A method to quantify the effects of human disturbance on animal populations. Journal of Applied Ecology 33:786-792.

Graham, H. 1971. Environmental analysis procedures for bighorn in the San Gabriel Mountains. Desert Bighorn Council Transactions 15:38-45.

Gutierrez-Espeleta, G.A., P.W. Hedrick, S.T. KalinowSKI, D. Garrigan, AND W.M. Boyce. 2001. Is the decline of desert bighorn sheep from infectious disease the result of low MHC variation? Heredity $86: 439-450$

Hanley, J.A., AND B.J. McNeil. 1982. The meaning and use of the area under a receiver operating characteristic (ROC) curve. Radiology 143:29-36.

Johnson, C.J., S.E. Nielsen, E.H. Merrill, T.L. McDonald, AND M.S. Boyce. 2006. Resource selection functions based on use-availability data: theoretical motivation and evaluation methods. Journal of Wildlife Management 70:347-357.

Johnson, C.J., K.L. Parker, D.C. Heard, and M.P. Gillingham. 2002. Movement parameters of ungulates and scale-specific responses to the environment. Journal of Animal Ecology 71:225-235.

KING, M.M. 1985. Behavioral response of desert bighorn sheep to human harassment: a comparison of disturbed 
and undisturbed populations. Doctoral dissertation, Utah State University, Logan, UT. 136 pp.

Krausman, P.R., B.D. Leopold, R.F. Seegmiller, and S.G. TorREs. 1989. Relationships between desert bighorn sheep and habitat in western Arizona. Wildlife Monographs 102:1-66.

Krausman, P.R., S.S. Rosenstock, and J.W. Cain III. 2006. Developed waters for wildlife: perception, values, and controversy. Wildlife Society Bulletin 34: 563-569.

Leslie, D.M., and C.L. Douglas. 1979. Desert bighorn sheep of the River Mountains, Nevada. Wildlife Monographs 66:1-56.

Leslie, D.M., and C.L. Douglas. 1980. Human disturbances at water sources of desert bighorn sheep. Wildlife Society Bulletin 8(4):284-290.

LighT, J.T. 1971. An ecological view of bighorn habitat on Mt. San Antonio. Pages 150-157 in Transactions of the First North American Wild Sheep Conference.

Light, J.T., AND R. WEAvER. 1973. Report on bighorn sheep habitat study in the area for which an application was made to expand the Mt. Baldy winter sports facility. Admin. Report, San Bernardino National Forest, San Bernardino CA. Pages 1-39.

LimA, S.L. 1998. Stress and decision making under the risk of predation: recent developments from behavioral, reproductive, and ecological perspectives. Advances in the Study of Behavior 27:215-290.

Loehr, J., M. Kovanen, J. Carey, H. Hogmander, C. Jurasz, S. Karkkainen, J. Suhonen, and H. YloNEN. 2005. Gender- and age-class-specific reactions to human disturbance in a sexually dimorphic ungulate. Canadian Journal of Zoology 83:1602-1607.

Longshore, K.M., C. Lowrey, AND D.B. Thompson. 2009. Compensating for diminishing natural water: predicting the impacts of water development on summer habitat of bighorn sheep. Journal of Arid Environments 73:280-286.

Longshore, K.M., C. Lowrey, and D.B. Thompson. 2013. Detecting short-term responses to weekend recreation activity: desert bighorn sheep avoidance of hiking trails. Wildlife Society Bulletin 37:698-706.

MacArthur, R.A., R.H. Johnston, and V. Giest. 1979. Factors influencing heart rate in free ranging bighorn sheep: a physiological approach to the study of wildlife harassment. Canadian Journal of Zoology 57:2010-2021.

Manel, S., H.C. Williams, and S.J. Ormerod. 2001. Evaluating presence-absence models in ecology: the need to account for prevalence. Journal of Applied Ecology 38:921-931.

Manly, B.F.J., L.L. McDonald, D.L. Thomas, T.L. McDonald, AND W.P. ERICKSON. 2002. Resource selection by animals: statistical design and analyses for field studies. 2nd edition. Kluwer Academic Publishers.

ManOR, R., AND D. SALTZ. 2005. Effects of human disturbance on use of space and flight distance of mountain gazelles. Journal of Wildlife Management 69:1683-1690

MaO, J.S., M.S. Boyce, D.W. Smith, F.T. Singer, D.J Vales, J.M. Vore, and E.H. Merrill. 2005. Habitat selection by elk before and after wolf reintroduction in Yellowstone National Park. Journal of Wildlife Management 69:1691-1707.

Markovchick-Nicholls, L., H.M. Regan, D.H. Deutschman, A. Widyanata, B. Martin, L.
Noreke, AND T.A. Hunt. 2008. Relationships between human disturbance and wildlife land use in urban habitat fragments. Conservation Biology 22:99-109.

Monello, R.J., D.L. Murray, and E.F. Cassirer. 2001. Epilogical correlates of pneumonia epizootics in bighorn sheep herds. Canadian Journal of Zoology 79:1423-1432.

Monson, G., And L. Sumner. 1981. The desert bighorn: its life, history, ecology, and management. University of Arizona Press, Tucson, AZ.

Mooring, M.S., T.A. FitzPatrick, T.T. Nishinira, and D.D. REISIG. 2004. Vigilance, predation risk, and the Allee effect in desert bighorn sheep. Journal of Wildlife Management 68:519-532.

Moreau, G., D. Fortin, S. Couturier, and T. DuCHESNE. 2012. Multi-level functional responses for wildlife conservation: the case of threatened caribou in managed boreal forests. Journal of Applied Ecology 49:611-620.

Naylor, L.M., M.J. Wisdom, and R.G. Anthony. 2009. Behavioral responses to North American elk to recreation activity. Journal of Wildlife Management 73:328-338.

Nellemann, C., and R.D. Cameron. 1998. Cumulative impacts of an evolving oil field complex on the distribution of calving caribou. Canadian Journal of Zoology 76:1425-1430.

Ordiz, A., O. Stoen, S. Saebo, V. Sahlen, B.E. PederSen, J. Kindberg, and J.E. Swenson. 2013. Lasting behavioral responses of brown bears to experimental encounters with humans. Journal of Applied Ecology 50:306-314.

Papouchis, C.M., F.J. Singer, and W.B. Sloan. 2001. Responses of desert bighorn to increased human recreation. Journal of Wildlife Management 65: 573-582.

Pauli, J.N., AND S.W. BuskiRK. 2007. Risk-disturbance overrides density dependence in a hunted colonial rodent, the black-tailed prairie dog Cynomys ludovicianus. Journal of Applied Ecology 44:1219-1230.

Rosenstock, S.S., W.B. Ballakd, and J.C. Devos JR. 1999. Viewpoints: benefits and impacts of wildlife water developments. Journal of Range Management 52:302-311.

Rubin, E.S., W.M. Boyce, AND V.C. Bleich. 2000. Reproductive strategies of desert bighorn sheep. Journal of Mammalogy 81:769-786.

Rubin, E.S., W.M. Boyce, C.J. Stermer, and S.G. TorRES. 2002. Bighorn sheep habitat use and selection near an urban environment. Biological Conservation 104:251-263.

Sappington, J.M., K.M. Longshore, and D.B. ThompSON. 2007. Quantifying landscape ruggedness for animal habitat analyses: a case study using desert bighorn in the Mojave Desert. Journal of Wildlife Management 71:1419-1426.

Shackleton, D.M. 1985. Ovis canadensis. Mammalian Species 230:1-9.

Singer, F.J., V.C. Bleich, and M.A. Gudorf. 2000a. Restoration of bighorn sheep metapopulations in and near western national parks. Restoration Ecology 8:14-24.

Singer, FJ., M.E. Moses, S. Bellew, and W. Sloan. $2000 \mathrm{~b}$. Correlates to colonizations of new patches by translocated populations of bighorn sheep. Restoration Ecology 8:66-74. 
Sokal, R.R., and F.J. RohlF. 1998. Biometry. W.H. Freeman Press, New York, NY.

Stankowich, T. 2008. Ungulate flight responses to human disturbance: a review and meta-analysis. Biological Conservation 141:2159-2173.

TaYlor, A.R., AND R.L. KNight. 2003. Wildlife responses to recreation and associated visitor perceptions. Ecological Applications 13:951-963.

Turner, J.C., C.L. Douglas, C.R. Hallum, P.R. Krausman, and P.R. Ramey. 2004. Determination of critical habitat for the endandered Nelson's bighorn sheep in southern California. Wildlife Society Bulletin 32:427-448.

[USFWS] United States Fish and Wildlife Service. 2000. Recovery Plan for Bighorn Sheep in the
Peninsular Ranges, California. United States Fish and Wildlife Service, Portland, OR.

Welles, R.E., and F.B. Welles. 1961. The bighorn sheep of Death Valley. U.S. National Parks Fauna Series 6:1-242.

YDEnBERG, R.C., AND L.M. DiLl. 1986. The economics of fleeing from predators. Advances in the Study of Behavior 16:229-249.

Received 1 June 2016

Accepted 9 January 2017

Published online 31 March 2017 